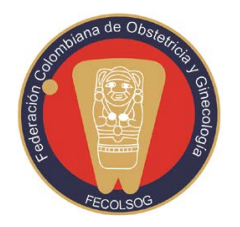

\title{
THE COMPREHENSIVE HEALTHCARE POLICY AND EDUCATION IN THE AREAS OF HEALTH
}

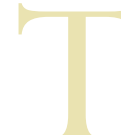

he study conducted by Bayron Manuel Ruiz-Hoyos and Dora Cardona-Rivas at Universidad del Quindío provides the information on how a research-action approach was used to define the competencies in the basic areas of training of a medical professional, and the process for their evaluation. The clinical areas are the second component of medical training in health sciences schools and have their own challenges when they involve, according to the Tuning model for Latin America, cross-cutting (communication, ethics, professionalism, management, research, education) and professional (clinical care and specific knowledge) competencies $(1,2)$ that must incorporate the competencies proposed by the Ministry of Health and Social Protection in its Comprehensive Healthcare Policy (3).

The Comprehensive Healthcare Model (MIAS in Spanish), presented under the Comprehensive Healthcare Policy of the Colombian Ministry of Health and Social protection, was created as a result of the Statutory Law on Health (4). MIAS is a new approach devised by the Colombian government in order to provide "timely access to effective and quality healthcare services with the aim of preserving, improving and promoting health". It also seeks to guarantee the right to health, pursuant to Law 1751 of 2015 (4).

The Comprehensive Healthcare Policy is supported by four key strategies: 1) primary healthcare focused on family and community health; 2) self care; 3) comprehensive risk management; and 4) a differential approach by territories and populations. Law 1438 of 2011 (5) focuses on primary healthcare as the strategy for solving the main health issues of the population, and the new model defines the realm of action of primary care services: "health promotion, specific protection and early detection, disease prevention, emergencies and low and intermediate complexity surgery, general dentistry outpatient service, general medicine, family medicine, paediatrics, obstetrics and gynaecology, internal medicine and surgery" (3).

According to the document released by the Ministry of Health and Social Protection, this model was the result of analyses that revealed the differences in the epidemiological profile of the country, and the access and equity gaps associated with geographic factors, urban and rural areas, and among population groups (3). As stated in the document, for 2013, maternal mortality among indigenous peoples was 6.8 times higher than among the afro-descendant population. The document also reports an increasingly low use of basic levels of care and a growing rate of use of high complexity care, greater than 90\%, affecting both the private and public health providers network. Regarding obstetric care, the report points to the fact that, whereas in 2007 " $48 \%$ of deliveries were referred to higher complexity centres from public primary care hospitals, by 2012, the figure had increased to $88 \%$, pointing to an incentive to perform Cesarean sections, which grew from 25\% in 1998 to 46\% in 2013" $(3,6)$. The same report claims that, following the reform of the health system under Law 100 of 1993, there was a "progressive loss of professional competencies in areas such as public health, communication, management, understanding of the context, humanization and caring and, in some cases, even in the clinical areas"; and "in the years following the reform, no training 
was provided in competencies associated with health education and promotion, primary healthcare, programme management and coordination, and family and community interventions" (3).

Training of human talent in health is linked by necessity to the health model in place. The role that the Health Management Organizations (Benefit Plan Management Organizations or EAPBs in Spanish) played solely as health contingency managers, together with the results of the health model and the market conditions triggered by Law 100 of 1993, resulted in the weakening of the public healthcare network as a source of training and hence the displacement and concentration of health education schools and students in those institutions with the capability of concentrating the users of the system. As a result, "despite the sustained growth of human talent starting in the 1990's", reflected in an increase in the rate of physicians from 12 to 18 per 1000 inhabitants between 2000 and 2014 (3), working and education competencies among today's healthcare workers are the reflection of the education and service provision conditions created by a healthcare model characterized by the use of payment for highcomplexity services adverse selection practices by the insurance companies, selective hiring, and control of spending. This has led to a low resolving capability at the primary care level, "creating a trend towards hyper-specialized human talent" (3).

The reorganization of the health system under MIAS requires a new approach for the training of human talent at the technical, undergraduate and graduate levels. This new approach must embrace new teaching models aimed at strengthening and increasing competencies of general practitioners and of obstetricians and gynecologists in the primary care of women's health, including counseling, screening, vaccination, sexual health, family planning, pre-conception and antenatal care, legal abortion and intrapartum care and its complications (7), and family medicine with a focus on health promotion, prevention and care (3). Likewise, the model requires the implementation of continuing medical education for all healthcare staff under this new approach, centered on creating wellness based on the healthcare for disease and the risk management of health conditions related to the community and its members.

The reach of the comprehensive healthcare policy will only be realized if, starting with primary school, emphasis is placed on incorporating the necessary elements of self-care for adequate maintenance and improvement of individual and collective health, and if the elements of basic sanitation are articulated so that they can have an impact on the determinants of collective health, regardless of the social and cultural characteristics of our population. At the same time, insurance companies (EAPBs) must take ownership of their role of managing risk overall, evaluating interventions and their impact not only from the economic perspective but from the point of view of people's health, and guaranteeing service provision within the care protocols, respecting the autonomy and independence of the practitioners who train and practice their profession for the benefit of the people of this country.

\section{Jorge Andrés Rubio-Romero, MD, MSc, FACOG}

Professor (full)

Director, Medical Curriculum Area

Universidad Nacional de Colomba

\section{REFERENCES}

1. Proyecto Tuning América Latina 2004-2007. Competencias específicas y enfoques de enseñanza, aprendizaje y evaluación. Beneitone P, Esquetini C, González J, Marty M, Siu G, y Wagenaar R, eds. Reflexiones y perspectivas de la Educación Superior en América Latina. Informe final. España: Universidad de Deusto y Universidad de Groningen; 2007.

2. Pinilla AE. Modelos pedagógicos y formación de profesionales en el área de la salud. Acta Medica Colomb. 2011;36:204-18.

3. Ministerio de Salud y Protección Social. Política de Atención Integral en Salud [Internet] [visitado 2016 Jun 22]. Disponible en: https://www. 
minsalud.gov.co/Paginas/politica-integral-deatencion-en-salud.aspx

4. Congreso de Colombia. Ley 1751 de 2015. Diario Oficial 49427, febrero 16 de 2015.

5. Congreso de Colombia. Ley 1438 de 2011. Diario Oficial 47957, enero 19 de 2011.

6. Rubio-Romero JA, Fonseca-Pérez JE, Molina S, Buitrago Leal M, Zuleta JJ, Ángel-Müller E, et al. Racionalización del uso de la cesárea en Colombia.
Consenso de la Federación Colombiana de Obstetricia y Ginecología (FECOLSOG) y la Federación Colombiana de Perinatología (FECOPEN). Rev Colomb Obstet Ginecol. 2014;65:139-51.

7. Education Committee of the Council on Resident Education in Obstetrics and Gynecology (CREOG). Educational Objectives: Core Curriculum in Obstetrics and Gynecology. 10th ed. Washington DC: American College of Obstetricians and Gynecologists; 2013. 